\title{
Analysis of Some Research Works on Uyghur Language*
}

\author{
Aisikaer Yushayini \\ School of Uyghur Language and Culture \\ Northwest Minzu University \\ Lanzhou, China 730030
}

\author{
Wusiman Jumai** \\ School of Uyghur Language and Culture \\ Northwest Minzu University \\ Lanzhou, China 730030 \\ **Corresponding Author
}

\begin{abstract}
Scholars at home and abroad have published many research works and papers in the field of Uyghur language research since the beginning of the 20th century. Among them, the representative works are A Grammar of Old Turkic written by Marcel Erdal, Turkic Grammar in Ancient Times written by A von Gabain, Introduction to Chagatay Uyghur Language written by Abudulufu Fulati, Chagatay Manual written by Janos Ekman, Modern Uyghur Language translated by Chen Shiming and Liao Zeyu, Modern Uyghur Grammar written by Hamiti Tiemuer, Modern Uyghur Reference Grammar mainly edited by Litifu Tuohuti and Study on the History of Uyghur Language written by Chen Zongzhen. This paper mainly introduces the significance of characteristics of these works in the study of Uyghur language and explores their similarities and differences.
\end{abstract}

Keywords-Uyghur language; historical periods; existing problems; significance

\section{INTRODUCTION}

For the historical periods of Uyghur language, scholars at home and abroad have different principles for classification, so the structure of differentiation is also different. So far, there is no universally recognized and unified classification. China's linguists such as Mr. Chen Zongzhen, etc. classify the historical periods of old and modern Uyghur language to be: 1) Huihe language period, from the 8th century to the 15th century. 2) Karakhanid Empire Turkic and Chagatay language period, from the 10th century to the 20th century. 3 ) Modern Uyghur language period, after the $1930 \mathrm{~s}^{1}$. In the process of Uyghur language research, there have been various rich research results on different historical periods at home and abroad. This paper introduces the representative research works of each period with the above classification method.

*This paper is a phased achievement of the central university special fund project of Northwest Minzu University of the first-level discipline of "Chinese language and literature" --Arrangement and Analysis of Babur Works (Risale-I Aruz manual) (31920180018) and Uygur Literature Research of Chaghatay (319201808112).

\section{See Chen Zongzhen: Study on the History of Uyghur Language} [M], Beijing, China Social Sciences Publishing House, January of 2016, Page 32-33

\section{SOME WORKS ON UYGHUR LANGUAGE RESEARCH}

\section{A. Turkic Grammar in Ancient Times}

Author: [Germany] A von Gabain, tanslated by: Geng Shimin, published by Inner Mongolia Education Press in August of 2004. Professor Annemarie von Gabain was a leading authority of Turkic research in the world. She spent her life working with Turkic, especially for literatures on old Turkic and old Uyghur language and the research on history, culture, religion and art of Xinjiang of China, having written dozens of monographs and more than two to three hundred papers on this subject. This book was first published in 1941. "Since it is the first book on old Turkic grammar in history and it has rich materials, clear and specific exposition, which is very practical, it won the reputation for the author immediately. ${ }^{2}$ "The Chinese version of this book was published in 2004. In addition to the introduction, this book also contains the characters applied by Uyghur writing (Turk Runic character, Uyghur character, Sogdian character, Manichaen character and Brahmi character). There are 369 pages including rich contents such as alphabets, voice summaries, world-building methods, morphologies, postpositions, syntaxes, grammar indexes, selected works and dictionaries, etc. It can really be said that this book is a basic reference book for studying old Turkic and old Uyghur.

\section{B. A Grammar of Old Turkic}

Author: Marcel Erdal, translated by: Liu Zhao, published by the Ethnic Publishing House in March of 2017. Marcel Erdal is a linguist and an internationally renowned scholar on studying Turkic with major works including Old Turkic Word Formation (1991) and A Grammar of Old Turkic (2004), etc. In addition to the original sequence and Chinese sequence, this book consists of Chapter 1: Introduction, Chapter 2: Font, Spelling, Phonology and Morphological Phonology, Chapter 3: Morphology, Chapter 4: Syntax, Chapter 5: Pragmatics and Modality and Chapter 6: Vocabulary Description, Appendixes (I. Proper Noun and Parallel Table, II. Index, III. Literature Abbreviation and

\footnotetext{
[Germany] A von Gabain. Turkic Grammar in Ancient Times [M], Hugejiletu, Inner Mongolia Education Press, 2004, Page 2 of Preface of the Chinese Edition
} 
Description), References and Translation Postscript, which has 641 pages totally. The author considered the following three questions when writing: "The first one is philologists who are interested in studying old Uyghur literature not yet published. The second one is Turkic scholars and Altay scholars who hope to explore the historical, genealogical or geographical relationships between Turkic languages or between Turkic languages and other related languages. The third one is linguists with diverse academic interests but with an interest in old Turkic grammar, as it can enlighten the study of general linguistics or typology." 3 This book attempts to make a comprehensive description of the grammar of old Turkic. The object of the description is the literature left over from ancient Turks around China. The author makes an in-depth study of linguistic data and a detailed analysis of data.

\section{Chagatay Manual}

Author: Janos Ekman (1905-1971), the English edition was published by Indiana University Press in 1966. Janos Ekman was an internationally renowned Turkic scholar. This book is a definitive work in the field of Chagatay Uyghur language research with totally 340 pages. The book emphatically discusses the phonetic and morphological features of Chagatay Uyghur language in detail. The book has been translated into Turkish and published several times since 2000.

\section{Introduction to Chagatay Uyghur Language Research}

Author: Abudulufu Fulati, published by Nationalities Publishing House in June of 2017. Abudulufu Fulati is a professor and doctor of Uyghur Language and Literature Department of Minzu University of China. His major academic works on Uyghur language and Chagatay Uyghur language include: Chagatay Language (wrote with Professor Hamiti, 1986, Kashgar Uyghur Language Publishing House), Collection of Chagatay Uyghur Language Research (Private Collected Papers, 1993, Nationalities Publishing House), Uyghur Lexicology (1995, Kashgar Uyghur Language Publishing House), General Theory of Chagatay Uyghur Language (2004, Nationalities Publishing House), Chagatay Uyghur Grammar (2007, Nationalities Publishing House), Morphology and Research of Uyghur Language (2011, Nationalities Publishing House) and Chagatay Uyghur Language Theory (2014, Kashgar Uyghur Language Publishing House), etc. This book consists of contents such as introduction, Chagatay Uyghur language introduction and Chagatay Uyghur Grammar, etc. These contents are put forward on the basis of the original texts of various literatures, international phonetic symbols and examples of Chinese annotations, which are of high value. There are 470 pages totally.

\section{E. Modern Uyghur Language}

This book is based on Uyghur Division of Academy of Sciences of Kazakh Soviet Socialist Republic, which is a

[Turkey] Marcel Erdal. A Grammar of Old Turkic [M], Beijing, Nationalities Publishing House, 2017, Page 6 7 more systematic teaching book published in Slavic language from Uyghur edition by Alma-Ata in 1966 (the Uyghur edition was published by Xinjiang People's Publishing House in February of 1985 and the Chinese edition was published in October of 1987). It consists of four parts including lexicology, phonetics, morphology and syntax with totally two volumes. The original first volume (Kazakh edition) Lexicology and Phonetics was published in 1963 and the second volume Morphology and Syntax was published in 1966, translators: Chen Shiming, Liao Zeyu. There are 672 pages totally. Based on the theory of general linguistics and a large number of linguistic facts, this book gives a comprehensive and systematic description of the phonetics, vocabulary and grammar of Uyghur language, which has abundant content, wide range and detailed materials. Although this book sticks to the traditional grammar, Russian is attached in some positions and some contents in the book are slightly different from the Uyghur language in Xinjiang, it is still a rare good book from the perspective of the content and depth described.

\section{F. Modern Uyghur Grammar}

Author: Hamiti Tiemuer, published for the second time by Nationalities Publishing House in May of 2011 (published for the first time in 1987). Hamiti Tiemuer (19352006) was a Chinese linguist who had devoted his life to the Party's national education cause. This book can be said to be the monumental research result of regularization in the history of Uyggrahur linguistics due to the integration of his lifetime breakthrough research results, so this book was translated and published in English. This book has 470 pages totally and it mainly aims at Uyghur morphology, including the basic concept of grammar, the lexical nature of modern Uyghur language and various word categories and their syntactic features, etc. Although this book is called Modern Uyghur Grammar, its detailed elaboration on the syntactic features of various parts of speech and verb predicate forms has laid a solid foundation for the syntax part.

\section{G. Modern Uyghur Reference Grammar}

Author: Litifu Tuohuti, Aierken arezi, Maola Niyazi and Muzaipaer, published by China Social Sciences Publishing House in December of 2012. This book is "based on the research results left by older grammarians such as Hamiti Tiemuer, etc. with summarizing and absorbing the latest domestic and foreign research achievements, especially the breakthrough research achievements made in China's reform and opening up over the past 30 years." This book has 454 pages totally and consists of contents including introduction, phonetic system of Uyghur language, lexical categories and grammatical features of Uyghur language, functional language categories and grammatical features of Uyghur language and syntactic structure of Uyghur language, etc. This book abandons the description frame with taking the structuralism theory as the core in the past, takes Uyghur language fact as the starting point, takes the generative

Litifu Tuohuti, Editor-in-Chief. Modern Uyghur Reference Grammar [M], Beijing, China Social Sciences Publishing House, 2012, Page 1 of Preface 
grammar theory as the guidance and strives for the breakthrough description and the explanation effect.

\section{H. Study on the History of Uyghur Language}

Author: Chen Zongzhen, published by China Social Sciences Publishing House in January of 2016. In addition to the introduction, this book includes contents such as phonetics, vocabulary, morphology and syntax, etc. Each item is represented by a unified phonetic symbol on the basis of Turkic literature, Uyghur literature, Karakhanid Empire Turkic literature, Chagatay Uyghur literature and Uyghur characteristics, expounding the development and evolution of phonetics, vocabulary, morphology and syntax of old and modern Uyghur language. This book points out some major changes and special examples and explores the social or phonetic reasons for the changes, so as to show that Uyghur people have been deeply influenced by Arabic, Persian and Islamic culture since they believed in Islam and the inherent laws of their phonetics, vocabulary and grammar have changed. This book has 600 pages totally.

Although the publication of the above research works is of great significance to Uyghur language study, there are some differences and problems in each research work. The following points out the differences, existing problems and significance.

\section{SIGNIFICANCE OF THE ABOVE RESEARCH WORKS}

These works are of great significance for the further study of the various components of Uyghur language, for the recognition of the evolutionary process of phonetics, lexicology and syntax and for the standardization of Uyghur language.

In each period of history, a powerful research team has been formed. In each period, various aspects of language have been studied comprehensively and a certain scale has been formed. These works can serve as mirrors for each other, that is to say, they have the function of making up for each other. We can see that the above works also provide abundant and relatively loose data sources and information for scholars in this field.

In order to have a consensus on terms, periods, data sources and phonetic symbols, researchers use uniform terms and phonetic symbols. The development history of Uyghur language has outlined a relatively perfect degree.

The research results have been further consolidated through the mutually beneficial cooperation and complementary advantages of domestic and foreign researchers. Provide research methods and theoretical knowledge to new scholars and play a certain role in broadening the horizon.

Researchers on old Turkic believe that old Turkic has eight vowels (some believe nine), which are divided into front vowels and back vowels. The works described above are all marked with international phonetic symbols and with particular attention to vowels and harmony.
Some books have provided vocabulary, which is of great convenience to scholars.

\section{DIFFERENCES AND SOME EXISTING PROBLEMS}

There are some different opinions on the research results due to different sources of materials, limitations and research methods of each work. For example, there are some obvious differences among the three books on Modern Uyghur Language.

Some terms are different. For example: Hamiti Tiemuer and Abudulufu Fulati wrote "Chagatay Uyghur Language", Chen Zongzhen wrote "Chagatay Language" and Janos Ekman wrote "Chagatay".

There are differences in the use of international phonetic symbols. For example, expressions of vowels such as

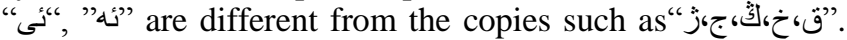
Some works do not pay attention to the expression of loanwords and long vowels.

\section{CONCLUSION}

In short, this paper selects the important works of Uyghur language in each period and gives a brief introduction. The aim is to provide more information to researchers and students in the field. Of course, the above works are not known by all people who study works of Uyghur language, but it is very important to recognize and learn representative research works in the future study and research.

\section{REFERENCES}

[1] Chen Zongzhen. Study on the History of Uyghur Language [M] Beijing, China Social Sciences Publishing House, 2016. (in Chinese)

[2] [Germany] A von Gabain. Turkic Grammar in Ancient Times [M] Hugejiletu, Inner Mongolia Education Press, 2004

[3] [Turkey] Marcel Erdal. A Grammar of Old Turkic [M], Beijing, Nationalities Publishing House, 2017

[4] Litifu Tuohuti, Editor-in-Chief. Modern Uyghur Reference Gramma [M], Beijing, China Social Sciences Publishing House, 2012. (in Chinese)

[5] Abudulufu Fulati. Introduction to Chagatay Uyghur Language Research [M], Beijing, Nationalities Publishing House, 2016. (in Chinese)

[6] [Hungary] Janos Ekman. Chagatay Manual [M], Indiana University Press, 1996

[7] Hamit Timur. Modern Uyghur Grammar (Morphology) [M], Nationalities Publishing House, 1987 (in Chinese). 